\title{
Effects of wildfire on the hydrology of Frijoles and Capulin Canyons in and near Bandelier National Monument, New Mexico
}

\section{Introduction}

In June 1977, the La Mesa wildfire burned 15,270 acres in and near Frijoles Canyon in Bandelier National Monument (BNM) and the adjacent Santa Fe National Forest, New Mexico (fig. 1). In April 1996,

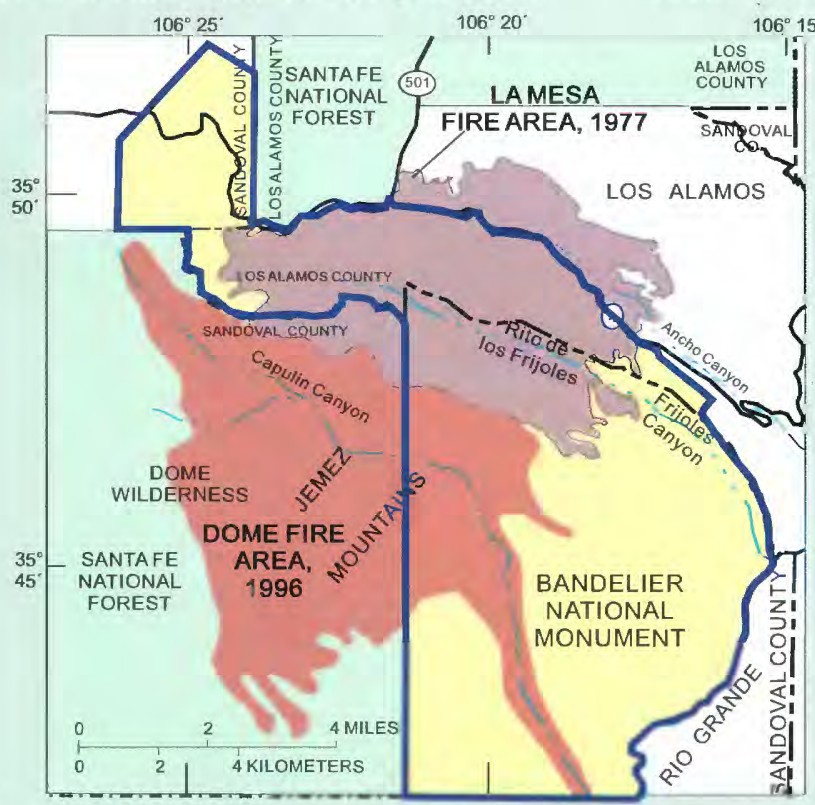

Figure 1. Location of Bandelier National Monument, extent of 1977 La Mesa wildfire, and extent of 1996 Dome wildfire. effects on streamflow after the 1996 Dome fire.

Post-fire hydrologic changes have been observed, but not often documented, for wildfires in Arizona, California, Idaho, Montana, New Mexico, and Wyoming. In 1996, the Hondo fire near Taos, New $106^{\circ} 15^{\circ}$ Mexico; the Buffalo Creek fire near Denver, Colorado; a fire in the Jicarilla Apache Reservation, New Mexico; and a fire in Mesa Verde National Monument all caused large increases in the magnitude of storm flows. In general, after each fire, peak flows increased, erosion and corresponding sediment transport increased, and channel geometry changed.

This Fact Sheet summarizes the effects of the 1977 La Mesa wildfire on the

hydrology of Frijoles Canyon and the 1996 Dome wildfire on the hydrology of Capulin Canyon in and near BNM from July 1996 to November 1998.

The study area is located in and near BNM in north-central New Mexico and includes parts of Frijoles Canyon and Capulin Canyon (fig. 1). Streamflow in these watersheds originates at higher elevations near the east rim of the Jemez Mountains, is in an easterly direction, and eventually enters the Rio Grande.

Rainfall was recorded and streamflow was monitored from 1996 to 1998 in and near Capulin Canyon after the 1996 Dome wildfire. The locations of selected rain gages, crest-stage gages, and streamflow-gaging stations are shown in figure 2. Slope-area and step-backwater indirect measurements were made at the three crest-stage gages and gaging station. The hydrologic assessment after the fire in Capulin Canyon was based, in part, on analysis of the gagingstation record for Frijoles Canyon collected before and after the

the Dome wildfire in BNM burned 16,516 acres in and near Capulin Canyon and the surrounding Dome Wilderness area. Both Frijoles and Capulin Canyon watersheds are characterized by archeological artifacts that could be affected by increased runoff and accelerated rates of erosion, which typically occur after a fire. In response to this concern, the U.S. Geological Survey (USGS), in cooperation with the National Park Service, conducted a study to monitor and document the wildfire

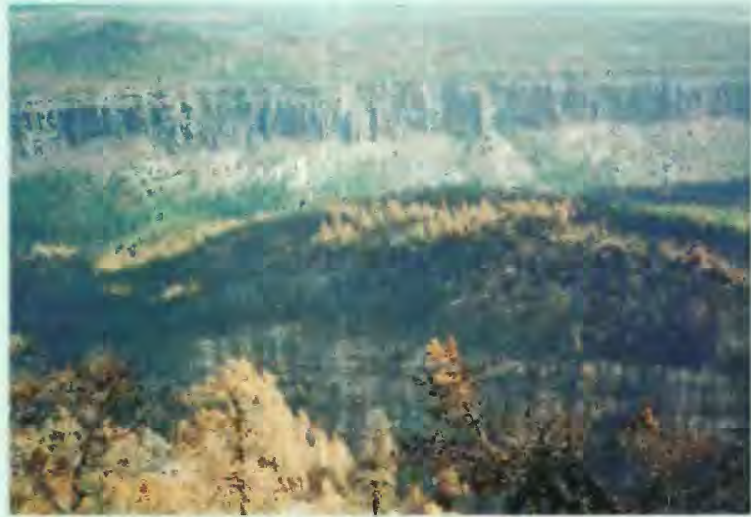

Part of burned area in Capulin Canyon after 1996 Dome wildfire. 1977 La Mesa fire. Suspendedsediment samples of La Mesa post-fire runoff were collected from 1977 to 1988 ; samples also were collected as part of the USGS National WaterQuality Assessment (NAWQA) Program from 1993 to 1995. For a complete description of the methods used during this study, the reader is referred to Veenhuis (2002). 


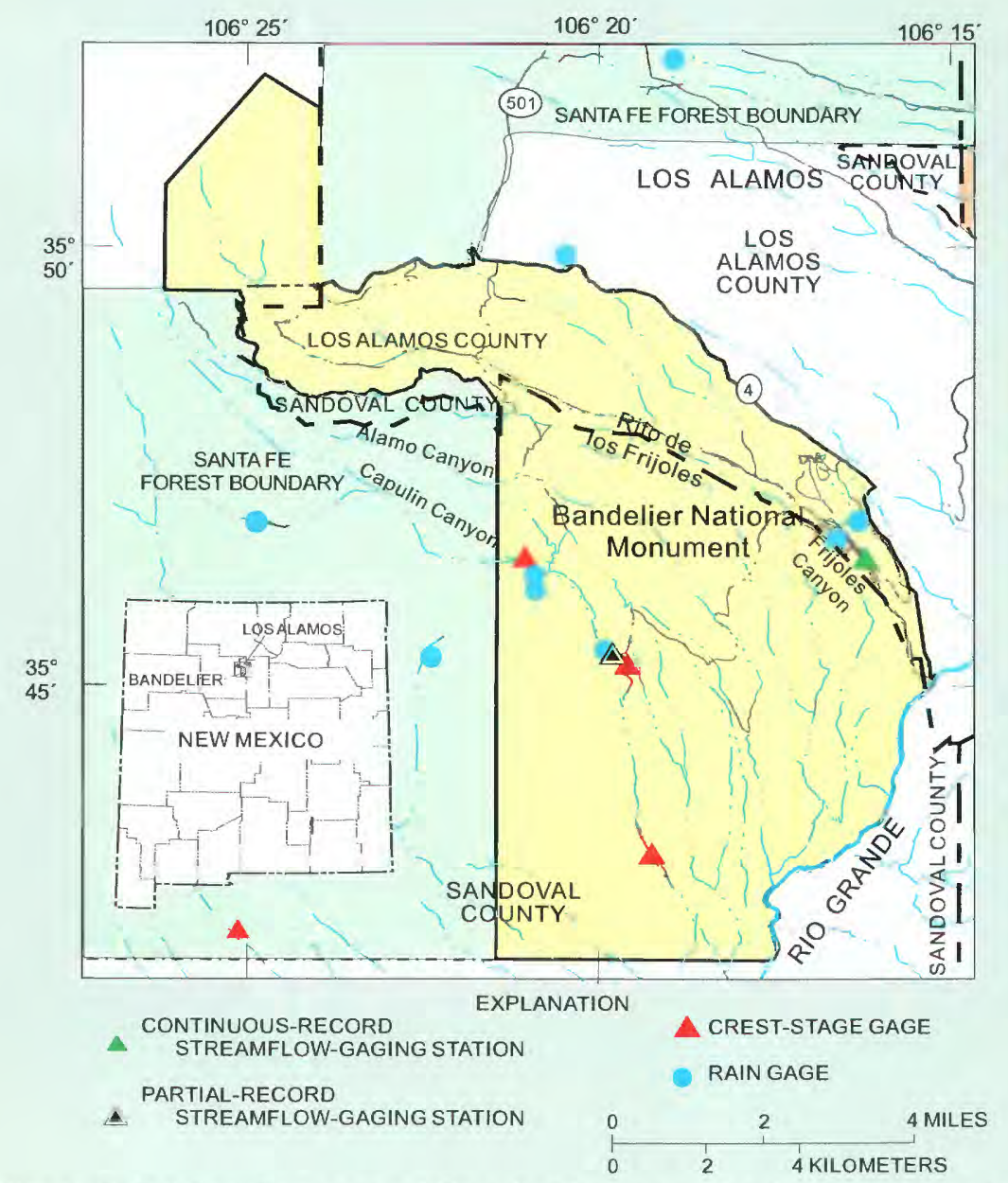

Figure 2. Frijoles Canyon and Capulin Canyon watersheds and location of selected gaging stations and rain gages.

\section{Pre-Fire Hydrologic Analysis}

Annual precipitation is about 15 inches per year in and near BNM (Miller and others, 1973). More than 50 percent of this precipitation falls during June, July, August, and September. Most annual peak flows in Frijoles and Capulin Canyons result from rainfall during these 4 months. Thirty-three percent of annual peak flows at the Frijoles Canyon and Los Alamos gaging stations occurred in August when about 19 percent of total annual rain typically falls. When large thunderstorms do not occur in individual canyon watersheds, about 20 percent of the annual peak flows generally result from snowmelt in March, April, and May.
Pre-fire annual peak flows in Frijoles Canyon from 1964 to 1969 ranged from 2.4 to $19 \mathrm{ft}^{3} / \mathrm{s}$ (cubic feet per second), with a median annual peak flow of 5.7 $\mathrm{ft}^{3} / \mathrm{s}$. Pre-fire annual peak flows in Capulin Canyon from 1985 through 1994 ranged from 1.1 to

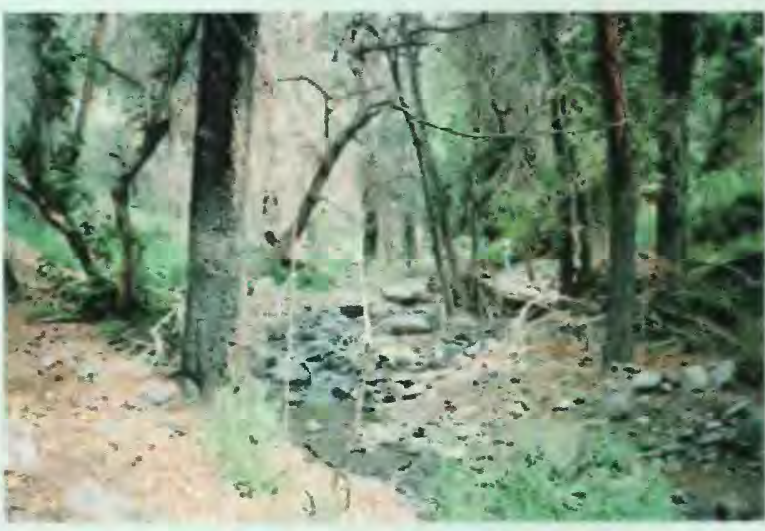

Average flow in Capulin Canyon.

an estimated $25 \mathrm{ft}^{3} / \mathrm{s}$, with a median annual peak flow of 15.2 $\mathrm{ft}^{3} / \mathrm{s}$. Peak flows that occurred prior to the 1996 Dome wildfire in Capulin Canyon are similar in magnitude to peak flows recorded prior to the $1977 \mathrm{La}$ Mesa wildfire in Frijoles Canyon.

During the NAWQA Program from 1993 to 1995,22 suspendedsediment samples were collected; concentrations ranged from 6 to 44 $\mathrm{mg} / \mathrm{L}$ (milligrams per liter), with a 3 -year median of $16 \mathrm{mg} / \mathrm{L}$ (fig. 3 ). Streamflow during sample collection ranged from 0.26 to 8.4 $\mathrm{ft}^{3} / \mathrm{s}$, with a median of $1.4 \mathrm{ft}^{3} / \mathrm{s}$. Because grasses and brush had reestablished on the exposed soil by 1993, samples probably were collected long enough after the fire to be representative of a prefire unburned watershed in this type of geologic setting.

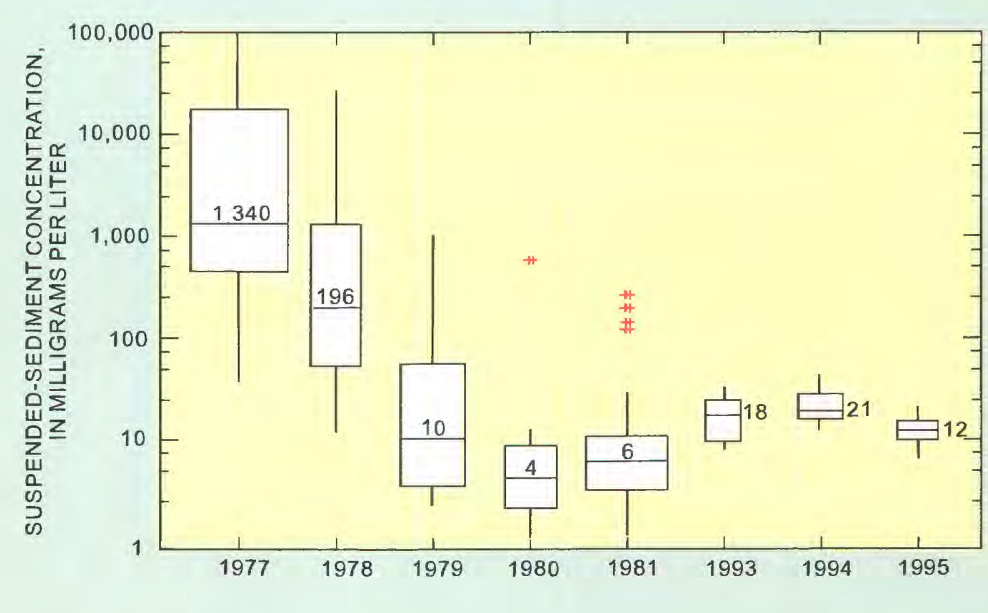

EXPLANATION

Outlier data value less than or equal to 3 times the interquartile range outside the quartile

Data value less than or equal to 1.5 times the interquartile range outside the quartile 75th percentile

Median value

25th percentile

Data value more than or equal to 1.5 times the interquartile range outside the quartile
Figure 3. Suspended-sediment concentrations in samples collected in Frijoles Canyon. 


\section{Post-Fire Hydrologic Analysis}

Because most peak flows occur during June, July, August, and September, this pattern is enhanced when a watershed is affected by fire because intense rainfall on exposed soil can produce greater peak flows. During the first year after the 1996 Dome wildfire, monthly precipitation was greater than the long-term average; most precipitation fell as low-intensity rainfall during the fall and spring, which helped to re-establish vegetation in the burned Capulin watershed. Maximum 24-hour rainfall for a given year can occur almost anytime during the year, but because fall and spring storms typically are less intense, these storms rarely cause the annual peak flow in a watershed.

Continuous streamflow data recorded at the Frijoles Canyon gaging station after the $1977 \mathrm{La}$ Mesa wildfire show that peak flows increased in Frijoles Canyon (drainage area about 18 square miles) from a maximum of $19 \mathrm{ft}^{3} / \mathrm{s}$ in 6 years of record $(1964$ 69) before the fire to $3,030 \mathrm{ft}^{3} / \mathrm{s}$ in July 1978 , about 1 year after the fire. In general, flood magnitudes decreased from July 1977 to June 1979; peak flows were never greater than $354 \mathrm{ft}^{3} / \mathrm{s}$ for 2 years after the fire. Even after 1979 , however, there was still no tree canopy for transpiration or evaporation, and interception of rainfall by vegetation was still less than pre-fire conditions, which effectively doubled the magnitude of post-fire mean annual flows. However, 22 years after the fire, flood magnitudes still have not completely returned to pre-fire magnitudes. Peak flows appear to be more pronounced for about 3 years after the fire. As growth of vegetation continued during the second year, peak flows were about 10 to 15 times the pre-fire peak flows. During the third year, peak flows decreased to about three to five times the pre-fire maximum peak flow.

During the 6 years prior to the $\mathrm{La}$ Mesa fire in Frijoles Canyon, the maximum peak flow was $19 \mathrm{ft}^{3} / \mathrm{s}$. From 1977 to 1979 , the number of peak flows greater than 19 $\mathrm{ft}^{3} / \mathrm{s}$ was 15 in 1977,9 in 1978 , and 5 in 1979 (fig. 4).

Of these

flows, seven were greater than $100 \mathrm{ft}^{3} / \mathrm{s}$ in 1977 and again in 1978 and three were greater in 1979. Similar to pre-fire peak flows, most of the larger flows occurred during July,

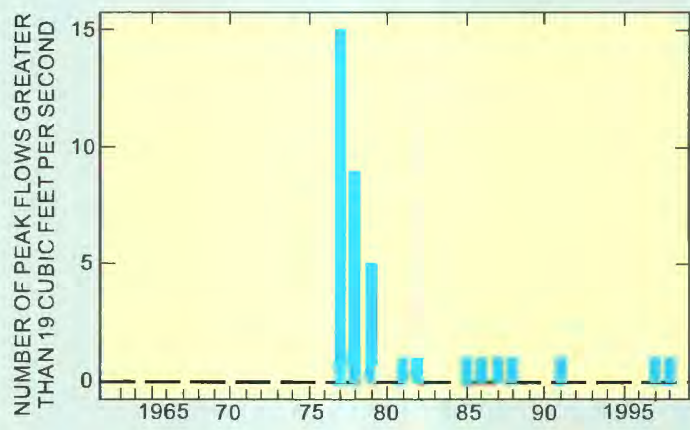

Figure 4. Number of peak flows greater than $19 \mathrm{ft}^{3} / \mathrm{s}$ in Frijoles Canyon.

August, and September; however, four flows greater than $100 \mathrm{ft}^{3} / \mathrm{s}$ were related to remnants of a Gulf of Mexico hurricane in November 1978.

Runoff in Capulin Canyon during a storm on July 10 , 1996. Silvery color of water is due to ash.

The maximum peak flow recorded in Capulin Canyon (drainage area about 14.1 square miles) after the 1996 wildfire was $3,630 \mathrm{ft}^{3} / \mathrm{s}$. Peak flows decreased to less than $400 \mathrm{ft}^{3} / \mathrm{s}$ in 1997 despite some large rainfalls within the watershed (Veenhuis, 2002). The reestablishment of vegetation the first year after the wildfire is probably responsible for most of the decrease in flows. By 1998, peak flow in the canyon had decreased to less than $160 \mathrm{ft}^{3} / \mathrm{s}$, but still was an order of magnitude larger than the pre-fire median annual peak flow. Peak flows at the most downstream gaging station in each canyon were about 160 times the maximum recorded peak flow prior to the fires. Increases in peak flows in response to the 1977 and 1996 fires are quite similar (fig. $5)$.

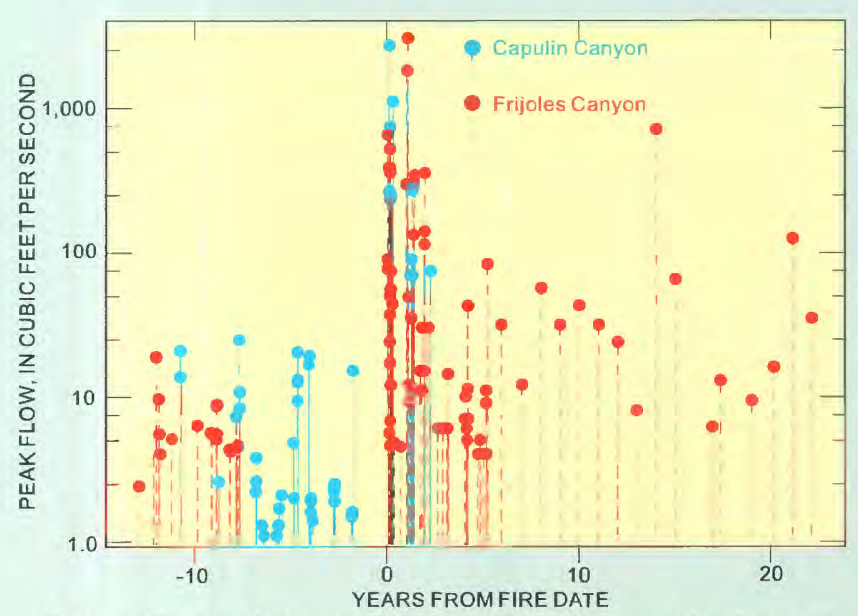

Figure 5. Peak flows in Frijoles Canyon before and after the 1977 La Mesa wildfire and in Capulin Canyon before and after the 1996 Dome wildfire. 
Maximum post-fire peak flows in Frijoles and Capulin Canyons and maximum peak flows in northcentral New Mexico in relation to drainage area (Waltemeyer, 1996) are shown in figure 6 . Although maximum post-fire peak flows in these two canyons are orders of magnitude larger than pre-fire peak flows, they are no larger than what was measured for similar drainage areas in north-central New Mexico. When large floods occur in watersheds that lack effective particular drainage area is more a function of rainfall intensity.

The median suspended-sediment concentration in samples collected after the La Mesa wildfire was 1,340 vegetative cover, the peak flow in a
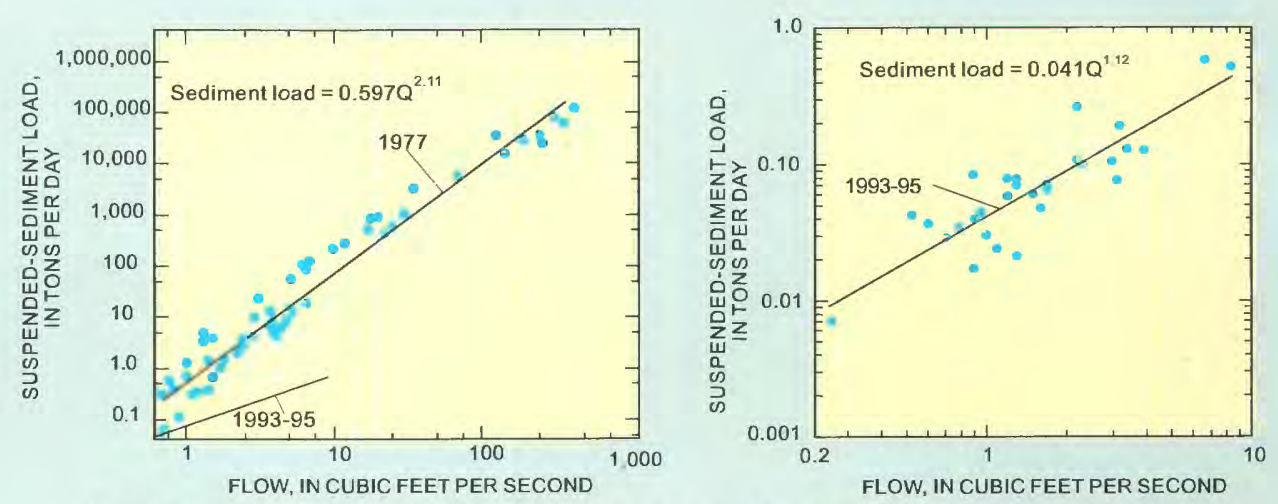

Figure 7. Instantaneous suspended-sediment load compared to flow, Rito de los Frijoles.

Suspended-sediment concentrations in relation to flow in Frijoles

Canyon immediately after the 1977

fire and for 1993-95 are shown in

figure 7 . The relation between load and streamflow was used with mean daily

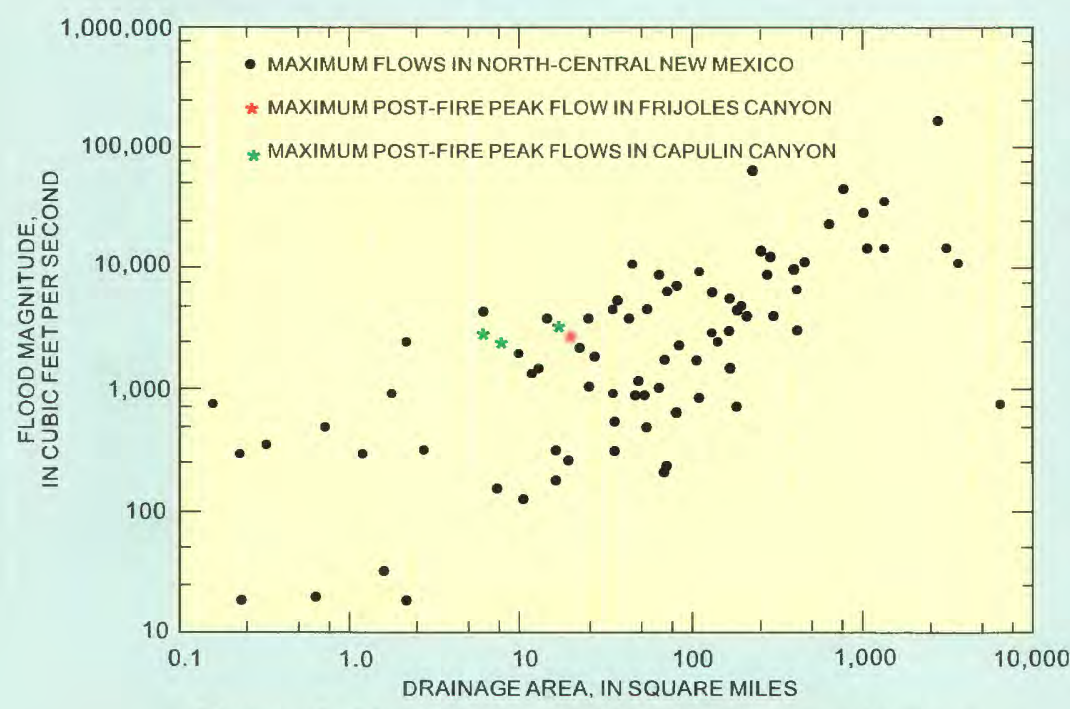

Figure 6. Maximum post-fire flood magnitudes (modified from Waltemeyer, 1996). streamflow to calculate annual suspendedsediment load. About 20 tons per year of suspended sediment were transported past the Frijoles Canyon gaging station during the 1993-95

$\mathrm{mg} / \mathrm{L}$ in 1977 in comparison with 16 $\mathrm{mg} / \mathrm{L}$ in samples collected from 1993 to 1995 (fig. 3). Suspendedsediment concentration and streamflow show similar patterns after a fire: a substantial increase the first year after the fire with a gradual decrease for about 3 years thereafter.

For more information contact: District Chief

U.S. Geological Survey

5338 Montgomery Blvd. NE, Suite 400 Albuquerque, NM 87109-1311

Email:

1sweiss@usgs.gov Internet:

http://nm.water.usgs.gov post-fire recovery period. In contrast, the first year after the fire, about 4,400 tons of suspended sediment were transported past the gaging station as a result of the increased magnitude and frequency of flows. Thus, during the first year

\section{References}

Miller, J.F., Frederick, R.H., and Tracey, R.J., 1973, Precipitationfrequency atlas of the Western United States, volume IV--New Mexico: National Oceanic and Atmospheric Administration NOAA Atlas 2, $43 \mathrm{p}$.

Veenhuis, J.E., 2002, Effects of wildfire on the hydrology of Capulin and Rito de los Frijoles Canyons, Bandelier National Monument, New Mexico: U.S. after the fire, suspended-sediment transport was about 220 times the annual suspended-sediment load in the recovering watershed.

\section{Cross Sections and Stream Gradient}

Because of the increased magnitude, frequency, and duration of flow and the resultant increase in suspended-sediment loads during the 1996 summer months, Capulin Creek in Capulin Canyon adjusted to the increase in runoff by widening and downcutting. The stream channel initially downcut in areas with steeper slope, then began to aggrade as sediment transported from upstream was deposited in channel reaches where slope and discharge decreased. The decrease in downcutting in the upper reach and the deposition in the lower reach in 1997 are indicative of a stream channel readjusting to less frequent and smaller floods. As peak flows in Capulin Canyon decreased in magnitude and frequency over time, in response to revegetation of the watershed, the stream channel has slowly started to stabilize.

Geological Survey WaterResources Investigations Report $02-4152,39 \mathrm{p}$.

Waltemeyer, S.D., 1996, Analysis of the magnitude and frequency of peak discharge and maximum observed peak discharge in New Mexico: U.S. Geological Survey WaterResources Investigations Report 96-4112, 79 p. 